\title{
THE BEAR WENT DOWN THE MOUNTAIN SÁMI LANGUAGE USAGE THEN AND NOW
}

\section{Introduction}

The bear had a lofty status in ancient myth and legend. This was especially so among circumpolar hunting groups such as the Sámi who venerated the animal. They resorted to a special system of language for communicating in such a manner that the bear did not understand their intentions. Yet, Sámi folktales portray the bear as a large, rather stupid animal easily duped by others such as the fox. In the 19 th century the Sámi were under relentless pressure to assimilate in the nationstates where they dwelt. One way they resisted assimilation was through a two-part communication system whereby messages had one meaning for outsiders but also contained coded information the outsiders could not understand. This essay, focusing on the code talk, attempts to answer the questions as to why and how the bear's stature changed so significantly from the early Arctic hunting culture to its status in Sámi folktales and argues that the manner of talking to bears formed the basis of the more recent Sámi oppositional communication.

On the basis of shared features among the northern boreal hunting groups scholars have hypothesized a circumpolar hunting culture. ${ }^{1}$ Some of these features are: 1) The importance of reindeer for their subsistence; ${ }^{2} 2$ ) The use of bark vessels such as the canoe; 3) Conical tents like the Sámi lavvu and the Native American teepee; 4) Use of the snowshoe and, after 6,000 BCE, skis in Eurasia ${ }^{3}$; 5) Cradle boards for transporting infants; and, in re the bear, 6) Post mortem rights, conciliatory address and synonymy.

\section{Bear in Pre-Christian Worldview}

The ancient religion of Sámi hunting groups combined animism - a belief that all aspects of nature possessed a soul - and polytheism with shamanism - where the noaidi or shaman with the help of the magic drum and joik was able to reach a state of ecstasy allowing his free soul to travel to the three levels of the world. Drawn on the drum with alder bark juice were figures representing various gods; at the center was Beaivi, the Sun and progenitor of the Sámi, usually a rhombus with rays extending in the four directions. Animals were also on the drum with the reindeer, an

\footnotetext{
${ }^{1}$ Gjessing, Gutorm. Circumpolar Stone Age. Acta Arctica, fasc. II. Copenhagen, 1944.

2 More so than the other features the reindeer served as the diffuser of culture.

3 The ski did not make it to North America until brought by Norwegian immigrants.
} 
essential part of the early hunters' subsistence patterns, most frequent followed by the bear. ${ }^{4}$ Half of the seventy odd preserved drums have bears on their skins. ${ }^{5}$ There was something supernatural about this large animal that disappeared in the late autumn after nature had withered only to return in spring, perhaps with cubs. The yearly hibernation was so remarkable to early hunters that it led to a bear cult. ${ }^{6}$ The bear was a symbol of strength and courage, of wisdom, of regeneration, rejuvenation and of motherhood. What's more, it inspired veneration and confidence and presented the ultimate test of courage to the hunter. The word Arctic finds its origin in the Indo-European word for bear: Gk. arktos, ursa from Lat. ursa (fem.) in the northern constellations Ursa Major (Great Bear) and Ursa Minor (Little Bear) and even the name Arthur (Middle Irish art) derive from the IE root *rkso- "bear" and attest to the significance of this animal in the north. *rkso, however, is itself a loanword from the Northern Tungus (Altaic branch of the Ural-Altaic languages) word for bear, raketa. In some ways the bear resembled humans. When it reared up on its hind legs it could walk erect with both heel and toe making contact with the ground (plantigrade manner of walking). ${ }^{7}$ And it could swing its arms.

\section{Bear As Object of Veneration: Evidence}

Circumpolar hunting peoples thought wild game to be sacred. In the shamanic experience "animals sometimes appear as messengers or intermediaries. ... [A]nimal spirits ... are the vectors through which the shaman accomplishes his extraordinary tasks beyond place and time." ${ }^{8}$ On his spirit journeys the noaidi often changed himself into a reindeer, bird or fish depending on where his soul was going. The men going out to hunt left through a special door (N. Sámi boańńu, S. Sámi båassjoe) and brought their quarry in through the same door; the women were not allowed to par-

\footnotetext{
${ }^{4}$ Odd Mathis Hítta. The Ancient Religion and Folk-Beliefs of the Sámi, Alta Museum, 1994: 12. There were often thongs hanging from the underside of the drum with pieces of metal or bone attached; some had the "penis bone of a bear" commemorating "the only animal that is 'related to man'."

5 Rolf Kjellström \& Håkan Rydving. Den samiska trumman. Stockholm, 1988: 26. Kjellström, though, interprets fewer of the figures on the drum skins as bears than does Ernst Manker in his Die lappische Zaubertrommel 1 from 1938.

${ }^{6}$ In the 5th century BCE Herodotus wrote of Salmoxis/Beleizis, a Thracian god who made an underground chamber and disappeared for three years. Rhys Carpenter, in a fascinating but speculative study, suggested that the name Salmoxis is derived from a Thracian word for hide and that the god is none other than a bear. Carpenter even suggests that the Odyssey and Beowulf are derived from the ancient bear's son tale. The underground chamber was, of course, the lair and the bear had become a supernatural spirit to early man. No mortal might enter this lair, for it would become his death in that he would lose his shadow (soul). The American tradition of Groundhog Day on Candlemas (February 2nd) was once bear's day, the day the bear came out of hibernation. If the bear saw its shadow it meant that it had not really been among the dead, so it would have to return to its lair and sleep another six weeks before it could herald the end of winter. Rhys Carpenter. Folk Tale, Fiction and Saga in the Homeric Epics. Berkeley, 1946.

${ }^{7}$ It is not easy to separate man from other animals taxonimically. Jacques Goimard suggested that no criteria sufficed "except possibly that of upright posture." Cf. Gonseth: 1 .

8 Marc-Olivier Gonseth "Man and animals - cultural, sociological, religious aspects." UNESCO Courier, Feb. 1988: 2.
} 
ticipate. ${ }^{9}$ In a religious sense no animal was as important as the bear. Yet no sacrifices were made to the bear. Furthermore, IE * rkso is not found in Germanic, Baltic and Slavic, the three IE branches that border on Finno-Ugric peoples to the north and east. Instead they use circumlocutions. In Germanic, for example, the English word "bear" means "the brown one." The Slavic word for bear means "honey-eater" and the Baltic word means "licker, the one who licks." Thus the bear word taboo spread to neighbors of the circumpolar groups.

Numerous bear graves from the 9 th century on found in forest and mountain areas throughout Scandinavia illustrate the respect humans showed for bears. In Northern Sweden there are thirteen finds of which six have been investigated archaeologically: the bones have been laid in a specific arrangement similar to their placement in the live bear with the cranium and shoulder blades at one end. ${ }^{10}$ In about half of the graves the bones have not been split. There is evidence in the bear ceremonials too that after the bear meat had been eaten the bones were carefully buried in a particular order. This helped ancient hunters assure the fertility of their wild prey. ${ }^{11}$

Nils Uddenberg has written "the large prey animals were seen as having well developed mental abilities, something that likely could result in their attaining a high moral status." 12 And Johan Turi wrote "the animals, the trees, the rocks, and other things have lost the faculty of speech, but they still have the faculty of hearing and understanding." 13 To counteract this animal intelligence early hunting groups resorted to two strategies - in part related - to deceive the bear. They used special language to disguise the hunters' intentions. And to prevent vengeance on the part of the bear's kin they proclaimed their innocence in the slaying of the bear and thereby deflected the blame onto others.

It was commonly thought that the bear could understand human language, at least on a fundamental level. Therefore, one could not use the real word for bear or parts of the bear's body; otherwise the bear would become aware of the hunters' intentions. There are two words for bear in Sámi: guovL, $a$ and in Swedish Sápmi bierd$n a .{ }^{14}$ The proscription from using these words applied not only to bear hunts but to

${ }^{9}$ Carl-Martin Edsman. Jägaren och makterna: Samiska och finska björnceremonier, Uppsala, 1994: 91-92 and Uno Holmberg. Lapparnas religion, Uppsala, 1996 (Swedish translation of Lappalaisten uskonto, 1915): 1.

10 Gunilla Edbom "BjṆrngravar" in Ingvar Svanberg and Håkan Tunón. Samisk etnobiologi: Människor, djur och växter i nor. Falun, 2000: 227. Cf. also Pehr Fjellström. Kort Berättelse Om Lapparnes Björna-fänge, Samt Deras der wid brukade widskeppelser. Stockholm, 1755. Facsimile edition with biography and commentary by Louise Bäckman, Umeå 1981: 35-59.

11 Shnirelman, Viktor A. "Grandfather bear; hunting rituals and animal worship in eariy Eurasian cultures." UNESCO Courier, Feb. 1988: 1.

12 Nils Uddenberg. Renarna, markerna och människorna. Nya Doxa, Nora 2000: 109.

13 Björn Collinder. The Lapps. New York, 1949: 164. Collinder says that this is "in his book on the Lapps" but gives no further reference.

14 If Bo Wickman is right guovL $a$ and bierdna may originally be noa words too. guovL $a$ may be related to Finnish kontia "to creep, to crawl" whereas bierdna is a loanword from Swedish björn. "The Origins of the Lappish Hunting and Fishing Terminology" in Harald Hvarfner (ed.) Hunting and Fishing. Norrbottens Museum 1965: 504. 
daily speech as well. ${ }^{15}$ Instead, three types of expressions (so-called noa words) were used: 1) circumlocutions based on the bear's characteristics such as muottat "the furclad one;" 2) metaphorical expressions such as meahcehas "the one living in the forests;" and 3) kinship terms such as luoduid eadni "mother of the wilderness." Harald Gaski suggests that using a kinship term would help give the bear a kind disposition toward people. ${ }^{16} \mathrm{~A}$ circumlocution such as lavdnji "turf" could allude to the color of the bear's hide.

Nils Gaup's 1988 film Pathfinder, the action of which takes place during the Lu i period some 700 years ago, includes a Sámi bear hunt and the ensuing ceremonial. As the men are heading out to hunt the bear a young boy, Ovi, is about to utter the word for bear. His mother prevents him from doing so by referring to the bear as dárffot "the one who resembles moss (in color)." Adult members of the siida were apparently aware of this taboo, and the children had to learn it as part of their acculturation. As Gaski points out, the Sámi, though respectful of the bear, were implicitly drawing a border "between the human intellect and the animal's nature." 17 By resorting to roundabout expressions when speaking about bears the Sámi were implicitly saying that their use of language was more sophisticated than the bear's. This special form of communication whereby the bear was unable to understand the symbolic content of the Sámi language I argue provided the model for the "elaborate...hidden messages conveyed in the more rebellious songs from the period of colonization." 18

Another way the Sámi attempted to deceive the bear or rather the bear's kin was to distort the facts by laying the blame for the bear's death on others such as men from Sweden, Germany or England. Samuel Rheen, in his 1671 description of a Swedish Sámi bear hunt and ensuing ceremonial, reports that when the hunters arrive at the place where the bear is to be consumed and are met by their wives, they sing out loud "Here come men from the land of Sweden, from Germany, England and all lands" and hence they themselves are not to blame. ${ }^{19}$ Using words from other languages would also divert attention from the bear's killers and help to prevent vengeance. The South Sámi used many Nordic loanwords in their bear ceremonials, e.g. instead of the South Sámi word for "nose" njuenie they used the Swedish word nos. ${ }^{20}$ In the Finnish epic Kalevala Louhi, the dame of Pohjola, furious that the people of Kalevala have recovered from the pestilence, sends a bear to wreak havoc on

\footnotetext{
15 Edsman op. cit. 93-101 and Louise Bäckman op. cit. 53.

${ }^{16}$ Harald Gaski “The Bear Doesn't Understand Metaphors: On Sámi Names for the 'Old man of the Wilderness" Unpublished manuscript: 1.

17 Gaski ibid. 2.

18 Harald Gaski. In the Shadow of the Midnight Sun: Contemporary Sami Prose and Poetry. Karasjok, 1997: 15.

19 Edsman, op. cit. 65.

20 The South Sámi reindeer herder Anta Pirak writes that a hunter was not permitted to brag about his bear hunting exploits and had to be respectful toward the bear; otherwise an "evil ear" might hear the boasting and perhaps take revenge. $20 \mathrm{He}$ adds that if a woman were to meet a bear in a cloudberry patch, she was supposed to lift up the front of her dress and say: "See, I'm a woman. Shame on you - get away from me. I don't intend to kill you." En nomad och hans liv. Stockholm, 1937: 79, 251, 256-57.
} 
Kalevala's cattle. ${ }^{21}$ Väinämöinen learns of this and has the smith Ilmarinen forge him a special spear with which he then dispatches the bear. Väinämöinen says " $\mathrm{My}$ own Otso, you my only, Good old Honeypaw, the handsome! Be not angry without reason; I am not the one who slew you, You yourself rolled off a shaft-bow, You yourself down from a pine bough" as if the bear's death had been accidental.

\section{Bear As Quarry}

If the bear was so venerated, why was it hunted? Thomas DuBois writes that the "ceremonial bear hunt sought to remove a fierce competitor from the local environment, while winning its power for the hunter and community and assuring its eventual reincarnation or return to the sky." 22 It provided the hunter with the chance to measure his strength and courage with that of the bear. When the Sámi hunters had come out on top, the bear's death was celebrated; even the bear participated. An elaborate "björnvisa" or bear song - really an antiphonal joik text in no fewer than 48 parts - was recorded in $1775 .{ }^{23}$ It reenacts many aspects of the bear ceremony from shortly after the felling of the animal to a few days later when all the meat had been eaten. The bear's joiks were sung either by the women or the men. Hence, the bear was "holy game" surrounded by a great deal of mysticism. However, Louise Bäckman, after looking at bear ceremonials among other peoples in Siberia, ascertains that not all successful bear hunts included celebrations. ${ }^{24}$

\section{Bear Ceremonial}

Such extensive, almost religious celebrations were widespread among circumpolar hunting groups from the Sámi and Finns in the west to the North American Indians. Some of the customs connected to the ceremonial, which had the goal of assuring future hunting luck, were sacrifice, prayer, divination, language taboos, exculpation and/or atonement from guilt, taboos for the women such as covering their eyes, peering through brass rings, not eating certain parts of the bear and abstinence from sexual activity. 25

The oldest Nordic depiction of the Sámi bear ceremonial is in the Norwegian royal chronicles Chronicon Regum Norvegil from 1606. Thereafter follow a number of descriptions of the ceremony including one by Samuel Rheen in 1671 and one by the Norwegian clergyman Petter Dass in the last decade of the 17th century. One of the

21 The Kalevala: Epic of the Finnish People. Tr. Eino Friberg. Otava 1988.

22 Thomas DuBois. Nordic Religions in the Viking Age. Philadelphia,1999: 48.

23 P. Holmberg(er) and G. Hasselbrink in Edsman op. cit. 72-79. Cf. also G. Hasselbrink "La chanson d'ours des Lapon. Essai d'interpretation d'un manuscrit du XVIIIe siŹcle concernant la chasse et le culte d'ours" in Orbis. Bulletin International de Documentation Linguistique, 13, 1964: 420-80 for a detailed study of the language in the ceremony.

24 Louise Bäckman "BjN̦rnen i samisk tradition" in Ingvar Svanberg and Håkan Tunón. Samisk etnobiologi: Människor, djur och växter i nor. Falun, 2000: 219.

25 Edsman ibid. 50 and Bäckman op. cit. 220-23. 
most thorough dates from 1755 and is by Pehr Fjellström who lived among the Sámi for some forty years. ${ }^{26}$

According to Sámi tradition and, for that matter, throughout the circumpolar area these elaborate rites of a religious nature owe their existence to the same sacred narrative: a young woman was forced to go into the forest to escape maltreatment from her brothers and she took refuge in a bear's lair. ${ }^{27}$ The bear returned, accepted her and they began a marital relationship. She gave birth to a son and she and the bear lived together for a long time while their son was growing up. Then the bear realized that his time on earth was up and told his wife to instruct the bear's slayers - her brothers - how to act so as to avoid revenge. This scenario dictated by the bear was then played out during every important bear hunt.

All members of the siida entered into a sacred period at the beginning of the hunt, which lasted until the end of the ceremonial. There were a number of aspects to the whole process, only a few of which will be mentioned here. Ringing in or encircling: the man who discovered the lair ringed it in, i.e. marked it in some fashion. The bear was thought to have a guardian spirit who fed the bear during the long hibernation. ${ }^{28}$ It was important that the ringing-in leave an opening through which the bear's guardian spirit could bring the bear a daily bowl of milk during hibernation and a bowl of blood right before the bear's death. The hunting party arrived in strict order with the one who discovered the lair first followed by the one who was designated to kill the animal.

Beating with branches: the dead bear was beaten three times with birch branches or the hunters skied over the bear three times. This custom goes back to the original myth where the bear's son asked for a share of the bear meat but was refused by the brothers. The son then beat the bearskin with twigs threatening to resurrect the bear then and there, after which he got his fair share of the meat. The one who killed the bear made a ring of soft branches and put it around the bear's nose and lifted it three times. A draft reindeer then pulled the bear back to the siida where preparations had been made - no woman could be on a sled pulled by that draft reindeer for the next year. The hunters announced their arrival with song, explaining that they had an honored guest with them.

The special door or boańn: after preparing the bear meat the hunters entered the dwelling through a special door, which the women were not allowed to use. The women spat alder bark juice - liejpie in S. Sámi, which also means menstrual blood - on the bear and on the hunters when they came in and when they handed meat to the women. This custom and its meaning have been extensively debated; it was likely an apotropaic measure intended to avert evil. ${ }^{29}$ Bäckman suggests that in the myth

\footnotetext{
26 Pehr Fjellström. Kort Berättelse Om Lapparnes Björna-fänge, Samt Deras der wid brukade widskeppelser. Stockholm, 1755. Facsimile edition with biography and commentary by Louise Bäckman, Umeå 1981.

27 Ibid. and Bäckman op. cit. 220. Also cf. the story of Amor and Psyche for the animal-husband theme.

28 Carl-Martin Edsman. "The Story of the Bear Wife in Nordic Tradition" in Ethnos 1956: vol. 1-2: 37.

29 Edsman op.cit. 92.
} 
the god of the hunt was in a hostile relationship with one of the female gods. Then the eating could begin and it might last for four days or more depending on how many people there were. The men ate the front part of the bear and the women the hind part. During this rite there could be an extensive joik antiphony as mentioned above. At the end the bear's bones were buried in a careful order and the men underwent purification and could then return to their wives.

\section{Sámi Bear Tales}

Turning to Sámi folktales the bear's situation is quite different. Granted folk tales and myths are not quite the same thing. Myths are generally pessimistic and reflect adult psychology, whereas folk tales tend to be more optimistic and deal with the problems of childhood. I have only considered a few of the tales and one late myth, but the overall pattern seems clear, viz. a rather ignominious outcome for the bear. Many of these tales were collected by J. K. Qvigstad with the help of a number of Sámi informants and they appeared in Samiske eventyr og sagn I-IV, 1927-29.

"The Fox, the Bear and the Mountain Sámi" begins with an etiological explanation for the bear's short tail. ${ }^{30}$ The bear meets a fox that has acquired a lot of fish. He asks the fox how he too might get hold of some fish - note that he does not simply take the fish from the fox. The fox tells him to stick his tail into a well and wait until it becomes heavy. He does so, and then it freezes. The bear loses his tail, beating a speedy retreat after the fox warns the owners of the well. The bear is understandably angry and manages to catch the fox but is fooled once again. The fox tells him about dressing up small birds and the bear becomes envious. The fox gets the bear to dig a pit, fill it with firewood and tie himself up after which the fox burns him to death.

In another tale "The Bear Shows the Lion A Human" a man meets a bear that wants to take him. ${ }^{31}$ The man says: "Wait a second! We should castrate each other. I'll castrate you today and you can do me tomorrow." The bear agrees to this, and the following day the man sends his wife to meet the bear. The bear notices that it is a woman and says: "Others have already castrated you, but I'll fix that up, for they haven't done it the right way." As if that weren't enough, later on the bear becomes frightened when a hare tells him that the wife has farted loudly.

In "The Fox Frightens the Bear and the Lion" the fox receives a visit from the bear and the lion and is afraid they will kill him. ${ }^{32}$ The three begin to talk about how strong they are. Then the fox tells them he knows someone stronger. The fox fetches a house cat. The bear and lion each climb a tree from which to glimpse this powerful creature. There is also a pig at the fox's place that digs in under one of the trees, keeping an eye open to view the strong creature. The cat, not knowing why he is

\footnotetext{
30 Similar to Qvigstad III: 2,2 .

31 This and the following three tales are in Brita Pollan. Samiske beretninger, 2. opplag. Oslo, 1999. This one is Qvigstad II: 9.

32 Qvigstad III: 8.
} 
there, chases a mouse under a tree and spots the shining eye of the pig and proceeds to scratch it out. The pig howls shaking the ground so that the dirt flies. The cat becomes scared and jumps up into the tree where the bear is. This frightens the bear, who believing the cat has killed the pig, quickly takes flight.

In "The Fox Frightens Wild Animals" a fox, a cat and a ram live together and nearby live a bear, a wolf and a lion. ${ }^{33}$

The fox overhears the bear tell his comrades that they should chase the fox, cat and ram away. The fox asks his comrades how they can protect themselves against such mighty enemies and comes up with a plan: the ram is to butt an empty barrel while the cat is supposed to sit on the stove, hiss and extend and retract his claws. The fox lies on the floor pretending to be terribly tired. Somehow they manage to frighten the three large animals. The fox is not yet satisfied and he and his two comrades pay a visit to the bear, wolf and lion, getting them to abandon their house with the bear losing an eye to boot.

Finally, "The Man and The Bear" is clearly a myth. ${ }^{34}$ Two men hunting grouse become separated in a snowstorm. One falls down a hole and when he lights a match he discovers he is in a bear's den. He doesn't expect to survive, but someone whispers into his ear that he will not die there. When he becomes hungry he notices that a hulder or gufihtar (subterranean) woman brings food to the bear. The man falls asleep, but when he awakens he feels full. Eight weeks later the bear sticks his paw through some pine branches creating an opening to the outside. The man returns home and reports what has happened. His neighbors urge him to lead them to the lair where they shoot the bear. In his death struggle the bear kills the man who had shared his lair. Later an old woman asks why they hadn't come to her, for she knew the bear would recognize this man. The feeding of the bear during hibernation is related to the ringing-in of the bear's den at the beginning of a bear hunt as discussed above.

\section{Transition to Herding}

The bear's loss of status was due primarily to the colonization of Sápmi by outsiders, including the enforced conversion to Christianity; this in turn gradually led to the depletion of the fur-bearing animals and the end of the wild reindeer hunting culture. The emerging nation-states, Denmark-Norway, Sweden-Finland and Novgorod (later Russia) considered Sápmi to be terra nullius, a land without owners. Using the traditional state-building alliance between church, king and settlers they began to make inroads into Sámi territory. ${ }^{35}$ Churches were built around the Gulf of Bothnia beginning in the 12th century and later along the Arctic coast. A church was consecrated at VardN, in East Finnmark in 1307 followed by a royal fortress, and

33 Ibid. 11.

34 Qvigstad IV: 239.

35 Einar Niemi. "Sami History and the Frontier Myth." In Harald Gaski (ed.) Sami Culture in a new Era: The Norwegian Sami Experience, Davvi Girji OS 1997: 62-85. 
Christian missionary activity began. Conversion was a lengthy process especially in the interior of Sápmi, for it wasn't until the latter half of the 17th century that the clergymen actually resided at the inland siidas.

The veneration of the bear had been an integral part of ancient Sámi hunting culture, which now came under attack as stocks of wild game diminished. It was a long process that accelerated toward the end of the 16th century. Since there were no borders north of Jämtland prior to 1595 , the Sámi were taxed by as many as three nation-states, all of whom were vying for valuable Sámi territory. ${ }^{36}$ The Sámi paid their taxes in pelts. On the European continent there was a large appetite for such, and from the middle of the 16th century prices jumped dramatically. ${ }^{37}$ In Sweden Gustav Vasa forced the birkarls (merchants controlling trade with the Sámi) to pay more to the Crown from 1553 on. His son Karl IX issued a decree in 1602 requiring the Sámi to pay their taxes in reindeer and stockfish: pelt prices had now fallen and the army needed meat. In 1607 the tax burden increased to two live reindeer per family, 150 pounds of stockfish as well as every tenth reindeer calf. There were no large herds of domestic reindeer in the 16th century; hence a crisis loomed for the Sámi of Sweden. The only way out for many was to increase the size of their domestic reindeer herds rapidly in the first decades of the 17 th century.

There had been tame reindeer for many centuries, both females used as decoys and males used as draft animals. ${ }^{38}$ The first type of herding developed among the forest and mountain Sámi of Northern Sweden, perhaps as early as the 16th century. ${ }^{39}$ This semi-nomadic form of herding was "intensive" in the sense that during spring, summer and fall the herd was confined to a rather small area and herding was combined with other activities such as reindeer milking as well as fishing and hunting of small game. Then during the 17 th century under the pressure of taxation herding gradually spread to other Sámi regions. In the mountainous areas of Sápmi reindeer herding was "extensive" or fully nomadic with long spring and autumn migrations.

The gradual move to reindeer herding in most areas of Sápmi spelled the end of the traditional hunting culture and weakened the rituals that were part of it. The intimate relationship hunters to the bear now slowly disappeared and bear ceremonials slowly faded away. Some of the bear customs survived into the 19 th century in the form of wedding songs where the bear was treated as an honored guest. "Such remnant songs speak of an age when the fates of men and nature were seen as clearly tied." 40

\footnotetext{
36 Björn Forseth. Samelandets historia. Solna 2000: 74-75.

${ }^{37}$ Lennart Lundmark. Så länge vi har marker - Samerna och staten under sexhundra år. Stockholm 1998: 30.

38 Veli-Pekka Lehtola. The Sámi People - Traditions in Transition. Aanaar 2002: 26-27.

${ }^{39}$ Rolf Kjellström. Samernas liv. Stockholm, 2000: 68.

${ }^{40}$ Leea Virtanen and Thomas DuBois. Finnish Folklore. Jyväskylä 2000: 147-48
} 


\section{Christianity and the Missionaries}

The church also played a significant role in lowering the bear's status. Once clergymen began to dwell among the Sámi at the inland siidas in the latter half of the 17th century they became zealous and brutal in their effort to eradicate the old Sámi worldview: noaidis (shamans) were killed, magic drums were burned and joiking was discouraged. The Church considered all joiking "to be inherently 'heathen, if not downright evil." 41 In order to survive, the old religion, which had been such an important part of the hunting culture, was forced to go underground. These early hunters believed that the gods influenced hunting luck and they relied on their noaidis to help locate wild game. ${ }^{42}$

Sacrifices were made at sieidis (sacrificial sites) to bring continued hunting success. But now the Sámi discovered that their traditional methods no longer worked; since resources were dwindling rapidly sacrifices were of no avail. The Sámi came to understand that it was outsiders who were to blame for all the hard times, and they began to strike back the only way they knew - with their language.

\section{The Sámi Language As Weapon}

The bear as a formidable adversary of the Sámi was gradually replaced by outsiders; however, the Sámi's method of communicating so that the bear would not understand did survive. This use of noa words and metaphorical language provided the model for what Gaski refers to as "two-part communication where one transmitted a message to Sámi listeners and an entirely different message to outsiders." 43 There were two stages in the evolution of this metaphorical system beyond avoiding the words for bear, and they both involved learning the Sámi language:

1) Young Insiders: It was a short step from using this mode of communication with bears to using it on younger members of the siida themselves so as to communicate only part of a message, intentionally or otherwise. For example, in the creation myth "The Son of the Sun's Courting in the Land of the Giants" the narrator had "to maintain a double communication, so that the children mainly understood the denotative content of the texts, while the grownups could enjoy a connotative level that sustained several meanings. This was especially challenging perhaps in erotic narratives, then as now ... (?)" 44 At the beginning of the poem you read:

Few men were there before

A lack of women for the men.

The man hugged his woman

Their blood they blended together. ${ }^{45}$

41 Håkan Rydving. The End of Drum-Time. Uppsala, 1993: 60, 78-83.

42 Harald Gaski. "When the Thieves Became Masters in the Land of the Shamans." Nordlit 15: Special Issue on NORTHERN MINORITIES. Summer, 2004: 7. http://uit.no/humfak/publikasjonar/24?SubjectId=1197\&From=0 43 Ibid. 1.

${ }^{44}$ Harald Gaski. Biejiien baernie. Sámi Son of the Sun. Beaivvi bárdni. Tr. John Weinstock. Davvi Girji, 2003: 90-91 for examples of the connotative meanings.

45 Ibid. 94. 
Such language was and is fitting for children, even though "hugged" can be interpreted more narrowly than on what most people would agree. As soon as you bring in the cultural, historical and social contexts you enter the realm of connotation. That this still applies to young people today can be seen in the following quote from Gaski: "As a little boy I remember one time witnessing two older men having a discussion with each other in a language I didn't understand, even though it was Sámi, and I understood the words they used. But the words were put together in a way that made them foreign, at the same time as there was a strange sound to them - a song, poetry, but I didn't know it yet at that time."46

2) Outsiders: This new system of double entendres and figurative language became necessary for the exchange of coded information among the Sámi in the presence of non-Sámi during the turbulent period of assimilation and colonization. The Sámi were no longer concerned with tricking the bear; now they had to trick outsiders. Just as the bear's grasp of the Sámi language had been basic, limited to nonmetaphorical utterances, now there were missionaries, agriculturalists, birkarls, and other representatives of the nation-states who were beginning to learn the Sámi language for various purposes, whether it be to gain a deeper understanding of the Sámi worldview in order to eradicate it more readily, to resolve disputes with the Sámi or to trade with them. The Sámi resorted to their skills in communicating on several levels at one time. Gaski speaks about an extra potential of a text that is not accessible to outsiders: "There is, nevertheless, a residue left in the text - something, which is not easily explicated through the methodical exposition of the subject. This something I like to think of as being a more or less culturally internal code or mode, which is hard to catch without a broad knowledge of the background and context of the story, song or myth." 47 He gives the following short joik text about an old bachelor who has not yet made his courting trip:

Gumpe borai soa $\sqrt{\text { novuoján }}$

Sáhpán ciebai gabbabeaskka

Báhcán lei vel muzetsággi

Gean ii oktage lean guoskkahan

The wolf ate the deer hitched for courting

The mouse gnawed the white fur coat

Still left was the thin, dark one untouched by a man's hand

\footnotetext{
46 "Folk Wisdom and Orally Transmitted Knowledge - Everyday Poetry In Adages, Rhyme and Jingles." Forthcoming in Gaski, DuBois and Weinstock, The Thief and the Shaman: Sámi Interrelations With Home and Neighbors, lállid Lagadus.

${ }^{47}$ Harald Gaski. "The secretive text: Yoik lyrics as literature and tradition." Nordiit nr. 5: 5. http://www.hum.uit.no/nordlit/
} 
I mention only that gabba and muzet in the Sámi original can refer to light-haired and dark-haired reindeer or woman respectively. The "wolf" might be another man, i.e. a rival to the bachelor, and hence below the surface meaning lies a complex drama between two men and two women, which would be accessible only to someone brought up in the culture. ${ }^{48}$

Such metaphorical play was beyond the grasp of those who had only a rudimentary knowledge of Sámi.

By the mid-twentieth century a new chapter in the sociolinguistic history of Sámi culture began. With the worst aspects of assimilation mostly in the past the Sámi discovered that to be effective advocates for their people and culture they had to master the languages of the majority in the nations where they resided. ${ }^{49}$ In Norway, for example, ethno-political activity by bi-culturally competent Sámi led to gains in rights and a Sámi Parliament in 1989. But that is another story.

\section{Conclusion}

Returning to the bear tales, we may have an example of what Lassi Saressalo calls defensive ethnic folklore. ${ }^{50}$ Perhaps in the end the bear became the outsider, the stal$l u$, who was doomed to fail in trying his wits with the fox, the Sámi.

\section{Povzetek}

\section{MEDVED SE JE SPUSTIL V DOLINO - RABA SAMIJSKEGA JEZIKA NEKDAJ IN SEDAJ}

Ko so bili Sámijci še lovci, so spletali o medvedu bajeslovne in pravljične pripovedi. Iz takih besedil se da dognati vloga medveda $v$ predkrščanskem svetovnem nazoru, češčenje medveda in slovesnosti v njegovo čast, njegova vloga kot plen, odnos (prostodušnega) medveda do (zvite) lisice. Sledil je prehod od lova do čredništva, do kolonizacije in pokristjanjevanja Sámijcev. Glavni nasprotnik Sámijcev zdaj ni bil medved, temveč tujci (trgovci, misijonarji itd.) Način govorjenja o medvedu (ki je bil tabu tema) so izkoristili proti tujcem. Četudi so se slednji naučili nekaj sámijščine, niso mogli razumeti pomena stavkov, ki je temeljil na metaforah govorjenja o medvedu.

\footnotetext{
48 Ibid. 13.

49 Harald Gaski (ed.). Sami culture in a New Era: The Nonwegian Sami Experience. Karasjok, 1997: 19.

${ }^{50}$ Lassi Saressalo. "The Threat from Without: An Examination of Defensive Ethnic Folklore" in Saami Religion. Ed. Tore Ahlbäck. Stockholm, 1987: 251-57.
} 